\title{
Penyuluhan Dan Pelatihan Optimalisasi Matematika Terhadap Penguatan Ekonomi di Era Pandemi untuk Siswa SMA Muhammadiyah 2 Palangkaraya
}

\author{
Rospala Hanisah Yukti Sari*, Istighfaris Rezki, Reza Zulfikar Akbar \\ Fakultas Keguruan dan Ilmu Pendidikan, Pendidikan Guru Sekolah Dasar, Universitas Muhammadiyah Palangkaraya, \\ Palangka Raya, Indonesia \\ Email: 1rospalahanisah@gmail.com
}

\begin{abstract}
Abstrak-Matematika sebagai mata kuliah yang berorientasi terhadap implementasi di dalam kehidupan sehari-hari Matematika sebagai ilmu dasar dari ilmu yang lain, sehingga saling berkaitan dengan ilmu yang lainnya. Matematika dapat dikembangkan di berbagai bidang ilmu, termasuk ekonomi dan teknik. Oleh sebab itu, konsep-konsep di dalam matematika perlu diperkenalkan kepada mahasiswa. Dengan demikian, diharapkan pengenalan dan pelatihan matematika yang diimplementasi dalam bidang ekonomi dan teknik dapat membantu mahasiswa dalam usaha penguatan ekonomi terutama di era pandemi saat ini.
\end{abstract}

Kata Kunci: Matematika; Ekonomi; Teknik; Pelatihan; Pandemi, Covid-19,

Abstract-Mathematics as a subject that is oriented towards implementation in daily life. Mathematics is the basic science of other sciences, so it is interrelated with other sciences. Mathematics can be developed in other science, including economics and engineering. Therefore, concepts in mathematics need to be introduced to students. Thus, it is hoped that the introduction and training of mathematics that implemented in economics and engineering can help students in efforts to strengthen the economy, especially in the current pandemic era.

Keywords: Mathematic; Economic; Engineer; Training; Pandemic; Covid-19

\section{PENDAHULUAN}

Matematika merupakan salah satu cabang ilmu pengetahuan yang memiliki peranan penting dalam perkembangan ilmu pengetahuan dan teknologi (Siagian, 2016). Selain itu matematika juga berperan sebagai alat bantu dalam penerapan bidang ilmu lain. Dalam perkembanganannya matematika terus meningkat dari tahun ke tahun sesuai dengan tuntutan zaman, sehingga dapat menumbuhkan kreativitas manusia dalam mengembangkan dan menerapkan matematika sebagai ilmu dasar.

Salah satu cabang ilmu lain yang dapat dijadikan penerapan dari matematika adalahilmu ekonomi. Banyak aplikasi dari ilmu matematis yang dikembangkan kedalam ilmu ekonomi melalui penalaran yang logis, misalnya penerapan ilmu matematika mengenai fungsi linier terhadap fungsi permintaan dan keseimbangan pasar pada ilmu ekonomi (Barus, 2020). Munculnya permasalahan ekonomi yang kompleks disebabkan karena adanya hubungan antar variabel-variabel ekonomi dalam dunia nyata, hal ini akan menjadi fenomenauntuk membangun sebuah ide pada model ekonomi dengan melakukan penyederhanaanberdasarkan konsep ilmu matematis.

Permasalahan ekonomi terbesar yang sedang dihadapi sekarang ini merupakan dampak dari adanya pandemi COVID-19. Berbagai badan keuangan dunia memperkirakan pandemi COVID-19 akan menyebabkan kontraksi perekonomian dunia sebesar $-2 \%$ sampai $2,8 \%$ pada 2020 , dari sebelumnya tumbuh sebesar rata-rata $2,9 \%$ pada 2019. Pada saat yang sama, pandemi COVID-19 diperkirakan juga akan mengurangi arus perdagangan dan investasi global hingga 30\%, serta menambah volatilitas pasar keuangan dunia hingga $215 \%$. Berkurang drastisnya berbagai aktivitas perekonomian global pada gilirannya diperkirakan akan mengakibatkan tidak kurang 195 juta orang akan mengalami kehilangan pekerjaan dan antara 420 sampai 580 juta orang jatuh pada jurang kemiskinan (Kementrian Keuangan Republik Indonesia, 2020). Upaya yang dapat dilakukan guna meningkatkan ekonomi yaitu dengan mengadakan penyuluhan, pelatihan maupun workshop.

Berdasarkan hal tersebut dirasa perlu dilaksanakannya Penyuluhan dan Pelatihan Optimalisasi Matematika Terhadap Penguatan Ekonomi di Era Pandemi untuk Siswa Siswi SMA Muhammadiyah Kalampangan.

\section{METODE PELAKSANAAN}

Penyuluhan dan Pelatihan Optimalisasi Matematika Terhadap Penguatan Ekonomi di Era Pandemi untuk Siswa Siswi SMA Muhammadiyah Kalampangan dilakukan dengan beberapa tahapan kegiatan yaitu:
a. Observasi awal dan sosialisasi kegiatan.
b. Pembukaan pendaftaran kegiatan.
c. Pembuatan Modul.
d. Pelaksanaan kegiatan.
e. Pemberian tugas terstruktur.
f. Melakukan brainstorming. 
g. Evaluasi.

h. Publikasi, monitoring, dan pelaporan.

Adapun materi Webinar dan Praktikum yang akan diberikan kepada peserta kegiatansebagai berikut:

Materi I : oleh Rospala Hanisah Yukti Sari, M.Pd. yang memiliki latar belakang pendidikan di bidang Matematika akan menjelaskan materi mengenai: "Motivasi Belajar, Pengenalan dan Implementasi Matematika dalam Kehidupan Sehari-hari"

Materi II : oleh Istighfaris Rezki, S.E., M.E. yang memiliki latar belakang pendidikan di bidang Ekonomi akan menjelaskan materi mengenai: "Kupas Tuntas Pemanfaatan Matematika dalam Bidang Ekonomi".

Materi III : oleh Reza Zulfikar Akbar, ST., M.Sc yang memiliki latar belakang pendidikan di bidang Teknik akan menjelaskan materi mengenai: "Implementasi Matematikadalam Bidang Teknik untuk Menyongsong Penguatan Ekonomi di Era Pandemi”.

Adapun kegiatan penyuluhan dilakukan dengan sistemtatap muka seperti yang tertuang pada Tabel 1:

Tabel 1. Metode Pelaksanaan

\begin{tabular}{clc}
\hline No & \multicolumn{1}{c}{ Jenis Kegiatan } & Metode Pelaksanaan \\
\hline 1 & Penyuluhan dengan tema-tema : & Zoom \\
& a. Motivasi Belajar, Pengenalan dan & \\
& Implementasi Matematika dalam & \\
& Kehidupan Sehari-hari & \\
& b. Kupas Tuntas Pemanfaatan Matematika & \\
& dalam Bidang Ekonomi & \\
& c. Implementasi Matematika dalam Bidang & \\
& Teknik untuk Menyongsong Penguatan & \\
& Ekonomi di Era Pandemi & Tatap muka \\
\hline 2 & Pembagian Donasi Buku ke SMA & \\
& Muhammadiyah 2 Palangkaraya
\end{tabular}

Tabel 2 berikut menggambarkan mengenai rincian kegiatan pengabdian masyarakat.

Tabel 2. Rincian kegiatan

\begin{tabular}{|c|c|c|}
\hline No. & Waktu & Kegiatan \\
\hline 1. & 17 Juni - 31 Agustus 2021 & Persiapan modul dan perlengkapan \\
\hline 2. & 1 - 15 September 2021 & Menghubungi dan berkoordinasi dengan peserta \\
\hline 3. & 16 - 24 September 2021 & $\begin{array}{l}\text { Koordinasi dengan Peserta } \\
\text { Kegiatan Pengabdian }\end{array}$ \\
\hline 4. & 25 September 2021 & $\begin{array}{l}\text { Pelaksanaan kegiatan Seminar Trik Menguasai } \\
\text { Matematika }\end{array}$ \\
\hline 5. & 26 September 2021 & Persiapan kegiatan kedua \\
\hline 6. & 26 September 2021 & $\begin{array}{l}\text { Berkoordinasi dengan Kepala SMA Muhammadiyah } \\
2 \text { Palangkaraya }\end{array}$ \\
\hline 7. & 27 September 2021 & $\begin{array}{l}\text { Pelaksanaan Pemberian Donasi Buku untuk SMA } \\
\text { Muhammadiyah } 2 \text { Palangkaraya }\end{array}$ \\
\hline 8. & $\begin{array}{l}28 \text { September - } 30 \text { November } \\
2021\end{array}$ & $\begin{array}{l}\text { Pengumpulan Laporan, Video Kegiatan, dan artikel di } \\
\text { media massa }\end{array}$ \\
\hline
\end{tabular}

\section{HASIL DAN PEMBAHASAN}

\subsection{Penjelasan Kegiatan}

Dalam pelaksanaan kegiatan pengabdian kepada masyarakat ini, kami juga melibatkan alumni, staff dan mahasiswa. Tujuan workshop ini adalah:

1. Peserta kegiatan dapat memahami "Implementasi Matematika dalam Kehidupan Sehari-hari" sebagian salah satu alternatif Penguatan Ekonomi di Era Pandemi.

2. Peserta dapat membuat konsep tugas terstruktur dalam papan board edmodo.

3. Peserta mampu memiliki motivasi untuk meningkatkan kualitas pembelajaran daring disekolah mereka.

4. Peserta mampu mengetahui situs-situs yang menyediakan bahan dan sumber belajar sejenis macromedia flash untuk membant proses pembelajaran.

Kegiatan dilaksanakan sebanyak 2 (dua) kali, yakni pada hari Sabtu, tanggal 25 September 2021 dan 27 September 2021. Awalnya kegiatan pengabdian ini berjudul "Penyuluhan dan Pelatihan Optimalisasi Matematika terhadap Penguatan Ekonomi di Era Pandemi untuk Siswa di SMA Muhammadiyah 2 Palangkaraya ”. Namun, saat 


\section{Journal of Social Responsibility Projects by Higher Education Forum}

Vol 2, No 2, November 2021, Page 98-103

ISSN 2723-1674 (Media Online)

pelaksanaan kegiatan seminar, judul diperhalus menjadi “Trik Menguasai Matematika”. Hal ini dilakukan untuk meningkatkan minat siswa dalam mengikuti kegiatan, sehingga pelaksanaan kegiatan dapat berjalan dengan baik. Ada beberapa kegiatan yang dilaksanakan, yakni pelaksanaan pre test yaitu untuk mengetahui pemahaman siswa tentang materi matematika sebelum mengikuti seminar, pelaksanaan seminar Trik Jitu Menguasai Matematika, pelaksanaan post test yaitu untuk mengetahui pemahaman siswa tentang materi matematika setelah mengikuti seminar, pemberian donasi buku dan pembagian doorprize kepada siswa.

Sebelum dilaksanakan kegiatan seminar, panitia melakukan silaturahmi sekaligus menjelaskan teknis acara seminar kepada Kepala Sekolah SMA Muhammadiyah 2 Palangkaraya yang bertempat di Jl. Demak, Kalampangan, Kec. Pahandut, Kota Palangka Raya, Kalimantan Tengah. Setlah proses diskusi dengan Kepala SMA Muhammadiyah 2 Palangkaraya, maka kegiatan Seminar Trik Jitu Menguasai Matematika direncanakan dilaksanakan secara daring, karena saat pelaksanaan kegiatan masih diberlakukannya pembelajaran daring dan menyesuaikan dengan himbauan dari pemerintah untuk melakukan kegiatan secara daring. Peserta yang akan hadir dalam acara seminar berkisar antara 40 orang dalam satu ruangan, sehingga untuk mencegah terjadinya penularan covid-19 dan menerapkan protokol kesehatan, maka memperkuat untuk pelaksanaan seminar dilaksanakan secara daring.. Berbagai persiapan disusun, seperti memohon kesediaan narasumber mengisi kegiatan, pembuatan brosur kegiatan, pencarian peserta, pengiriman undangan kegiatan via WhatsApp.

\subsection{Tingkat Pemahaman Tentang Kegiatan Yang Berlangsung}

Seiring berjalannya waktu, pada Tanggal 25 September 2021 Pukul 07.00 WIB dilaksanakan seminar "Trik Jitu Menguasai Matematika" via Zoom. Peserta yang ikut berhadri sebanyak 41 Siswa yang diikuti oleh kelas X, XI, dan XII jurusan IPA dan IPS.

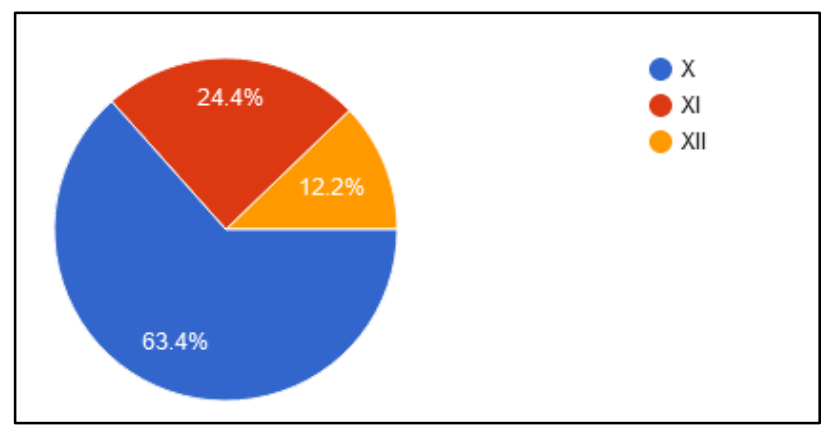

Gambar 1. Grafik Kelas Peserta Seminar

Berdasarkan Gambar 1, dapat diketahui bahwa mayoritas kelas yang mengikuti acara seminar yaitu Kelas X sebanyak 63,4\% atau sekitar 26 Siswa, kemudian disusul oleh Kelas XI sebanyak 24,4\% atau sekitar 10 Siswa dan terakhir kelas XII sebanyak 12,2\% atau sekitar 5 Siswa.

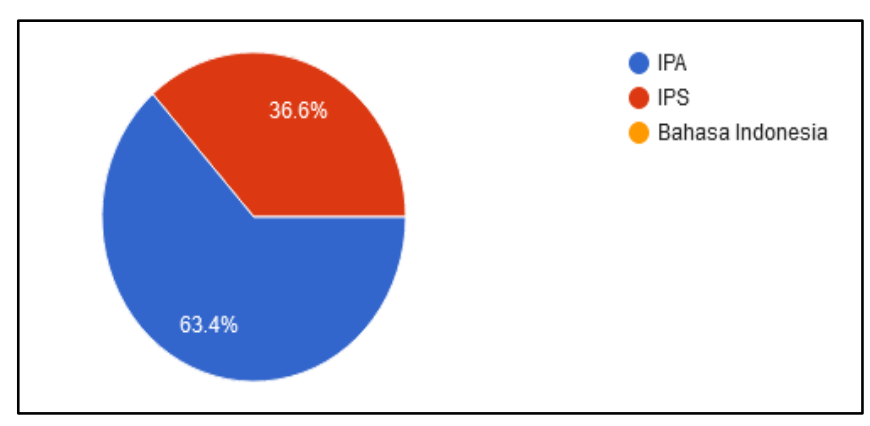

Gambar 2. Grafik Jurusan Peserta Seminar

Adapun Gambar 2, dapat diketahui bahwa mayoritas jurusan yang mengikuti acara seminar yaitu IPA sebanyak 63,4\% atau sekitar 26 Siswa, dan IPS sebanyak 36,6\% atau sekitar 15 Siswa.

Kegiatan seminar dimulai dengan pemberian pre test. Kegiatan pre test dilaksanakan dengan durasi ekitar 10 menit. Adapun pertanyaan yang diajukan kepada siswa saat pre-test yaitu:

1) Menurut Anda, Matematika itu pelajaran yang seperti apa?

2) Apakah Anda Menyukai Matematika?

3) Mengapa Anda memilih jawaban tersebut?

4) Bagaimana Menurut Anda Pembelajaran Matematika via Zoom?

5) Apa Langkah yang Anda Lakukan Ketika Kesulitan Belajar Matematika?

6) Menurut Anda, apa saja penerapan matematika dalam kehidupan sehari-hari? 


\section{Journal of Social Responsibility Projects by Higher Education Forum}

Vol 2, No 2, November 2021, Page 98-103

ISSN 2723-1674 (Media Online)

Hasil pre-test menunjukkan jawaban yang negatif, dimana siswa merasa bahwa Matematika merupakan pelajaran yang sulit untuk dipahami. Selain itu, beberapa siswa menganggap bahwa matematika merupakan pelajaran yang cukup rumit karena banyak rumus yang harus dipelajari serta dipahami. Namun, pendapat ini ternyata tidak menunjukkan bahwa siswa tidak menyukai matematika. Menurut hasil pertanyaan:"Apakah Anda menyukai Matematika", dapat dilihat pada Gambar 3:

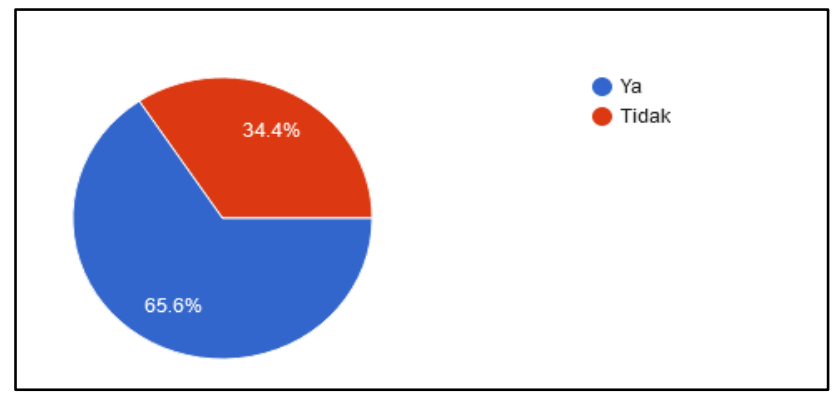

Gambar 3. Grafik Siswa yang Menyukai dan Tidak Menyukai Matematika sebelum Perlakuan

Berdasarkan Gambar 3, dapat diketahui bahwa mayoritas siswa menyukai matematika. Sebanyak 65,6\% atau sekitar 21 Siswa menjawab bahwa mereka menyukai matematika. Adapun alasan yang dikemukakan ketika mereka menyukai matematika, diantaranya karena menganggap bahwa matematika sangat berperan dalam hidup, matematika bisa melatih kemampuan otak, senang Belajar Matematika, matematika adalah pelajaran yang menantang, Matematika membantu kehidupan sehari dan ingin belajar lebih paham tentang matematika. Adapun alasan siswa yang tidak menyukai matematika, diantaranya: karena sering lupa terhadap rumus-rumus, tidak pandai dalam mengerjakan nya, kurang suka dengan pelajaran matematika dan matematika rumit sekali dan banyak sekali rumusnya.

Adapun pertanyaan pre test tentang pelajaran matematika dilaksanakan via zoom, respon siswa yang diberikan sangat beragam yaitu respon positif seperti menyenangkan, lebih efisien, dan mudah. Adapun respon negatif yang diberikan siswa ketika mereka melakukan pembelajaran matematika via zoom yaitu sulit dimengerti, membingungkan, Sulit karena biasanya ada gejala pada jaringan, dan guru matematika saya tidak pernah mengajak zoom.

Ketika siswa mengalami kesulitan dalam belajar matematika, ada beberapa langkah siswa dalam mengatasi kesulitan belajar matematika. Berikut respon yang diberikan oleh siswa dalam soal pre test ketika mengalami kesulitan belajar matematika, diantaranya: Mencari contoh materi di YouTube, mencari tau cara agar dapat menjawab, Berjuang, Mencoba terus sampai dapat, Mencari cara lain, Mencari di google, memahami rumusnya, Membaca kembali materi yang ada, Berusaha untuk mempelajari ny lagi, Mempelajarinya lebih giat, Menanyakan kepada guru matematika, diskusi, Memahami soal tersebut terlebih dahulu, Menggunakan kertas kosong untuk mencoret2, menggunakan gambr atau cara lain dan bertanya.

Adapun untuk pertanyaan dalam pre test tentang "penerapan matematika dalam kehidupan sehari-hari" ada yang menjawab kurang tahu, namun beberapa siswa juga memberikan respon beragam, diantaranya menghitung uang, belanja, jual beli, Saat berjualan dan saat membangun sesuatu, berhitung rumus, membantu orang orang berhitung saat bertransaksi jual beli, menghitung hasil penjualan , untung rugi, dan modal dan koordinat digunakan dalam dunia penerbangan.

Setelah siswa mengisi soal pre test, kegiatan dilanjutkan ke acara utama yaitu penyampaian materi. Materi pertama disampaikan oleh Ibu Rospala Hanisah Yukti Sari, M.Pd. yang akan menjelaskan tentang Motivasi Belajar, Pengenalan dan Implementasi Matematika dalam Kehidupan Sehari-hari. Saat penyampaian materi berlangsung, pemateri memberikan motivasi dengan mengubah mindset bahwa matematika itu mudah serta video tentang peran matematika dan bagaimana menguasai matematika, sehingga peserta terlihat antusias saat penyampaian materi. Adapun pemateri kedua disampaikan oleh Bapak Reza Zulfikar Akbar, tentang Implementasi Matematika dalam Bidang Teknik untuk Menyongsong Penguatan Ekonomi di Era Pandemi. Saat materi berlangsung, pemateri kedua juga memberikan video terkait dengan pembangunan negara yang terkait dengan matematika. Dengan demikian, siswa akan lebih termotivasi untuk belajar matematika. Penyampaian materi berlangsung hingga siang hari yaitu pukul 11.30 WIB.

Setelah penyampaian materi selesai, dilanjutkan tanya jawab dan pengisian post test. Adapun pertanyaan yang diajukan kepada siswa saat post-test yaitu:

1) Hal apa yang anda dapatkan dan rasakan setelah mengikuti acara ini?

2) Menurut Anda, apa saja penerapan matematika dalam kehidupan sehari-hari?

3) Strategi belajar matematika apa yang akan dilakukan setelah mengikuti acara ini?

4) Adakah pesan dan kesan untuk acara ini? 
Berdasarkan pengisian google forms oleh siswa setelah mengikuti seminar, berbagai respons positif diberikan oleh siswa terutama hal-hal yang didapakan dan dirasakan setelah mengikuti acara ini yaitu beberapa siswa mendapatkan wawasan baru terkait matematika, mendapatkan banyak ilmu tentang matematika, memulai paham bagaimana trik menguasai matematika, menambah semangat, menambah wawasan tentan bangun membangun, lebih memahami arti dari pelajaran matematika, pikiran saya terbuka tentang ilmu matematika, mendapatkan banyak pengalaman dan cara" mudah untuk menaklukkan matematika, sangat membantu saya dalam belajar matematika, lebih menyadari bahwa matematika itu ternyata ad di dalam kehidupan sehari hari dan Sedikit mengerti trik ${ }^{2}$ untuk menguasai matematika.

Respons positif yang diberikan oleh siswa berkorelasi positif dengan pemahaman siswa tentang penerapan matematika dalam kehidupan sehari-hari. Berbagai respons positif diberikan oleh siswa diantaranya siswa memahami bahwa banyak aspek penting dalam penerapan matematika terutama dalam semua aspek kehidupan kita. Selain itu, siswa juga memahami bahwa setiap aktifitas sehari hari berhubungan dengan matematika.

Harapannya dengan respon positif yang diberikan siswa, menambah motivasi dalam belajar matematika. Berbagai respon tentang strategi belajar matematika setelah mengikuti seminar ini diantaranya yaitu dengan cara memahami dan teliti, mempelajari lebih mendalam, lebih memahami lagi sebelum melakukan penghitungan, perbanyak latihan soal, menerapkan strategi yang ditampilkan di video tentang trik menguasai matenmatika, berusaha lebih memahami pelajaran matematika, lebih banyak mencari tau tentang matematika, mencari posisi yang enak dan nyaman, mengubah mindset, lebih rajin belajar matematika, pelajari trik dan rumus mudahnya, memahami soal terlebih dahulu, menggabungkan teknologi dalam kegiatan belajar matematika, menerapkan strategi tentang mengenai metode teknik pembelajaran dan belajar dengan perasaan nyaman,bahwa matematika tidak sesulit yang dilihat.

Dengan diselenggarakannya acara ini, memunculkan kesan positif dalam diri siswa dalam memahami matematika. Respons yang diberikan pun juga beraneka ragam, diantaranya acaranya baik, cukup memberi motivasi, menyenangkan dan bermanfaat, acara yang sangat menarik dan edukatif dalam penambahan wawasan matematika, lebih semangat lagi untuk belajar matematika, sangat membantu dalam memahami matematika, sangat memuaskan dan membantu menggerakkan pikiran penting nya ilmu matematika, sangat bermanfaat apa lagi dalam penjelasan tentang struktur bangun membangun sebuah alat transportasi, adanya acara ini saya lebih banyak mendapat kan tentang pelajaran matematika yang sebelumnya belum saya ketahui sebagian acara ini, sangat membantu sekali, dan menambah pengetahuan untuk menghadapi matematika, menambah ilmu dan penjelasanya untuk memudahkan matematika, sangat memotivasi untuk mulai menyukai matematika dan semoga acara ini bisa diteruskan kepada adek kelas selanjutnya.

\subsection{Dokumentasi Kegiatan}

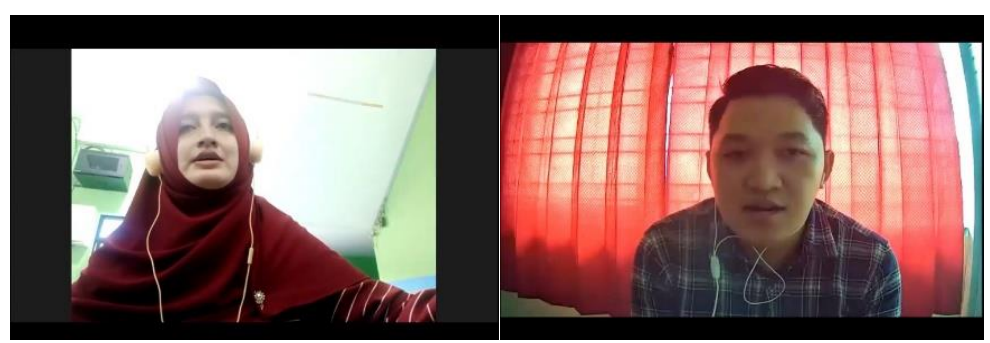

Gambar 4. Pemberian materi seminar kepada siswa

Materi pertama disampaikan oleh Ibu Rospala Hanisah Yukti Sari, M.Pd. yang akan menjelaskan tentang Motivasi Belajar, Pengenalan dan Implementasi Matematika dalam Kehidupan Sehari-hari. Saat penyampaian materi berlangsung, pemateri memberikan motivasi dengan mengubah mindset bahwa matematika itu mudah serta video tentang peran matematika dan bagaimana menguasai matematika, sehingga peserta terlihat antusias saat penyampaian materi. Adapun pemateri kedua disampaikan oleh Bapak Reza Zulfikar Akbar, tentang Implementasi Matematika dalam Bidang Teknik untuk Menyongsong Penguatan Ekonomi di Era Pandemi.

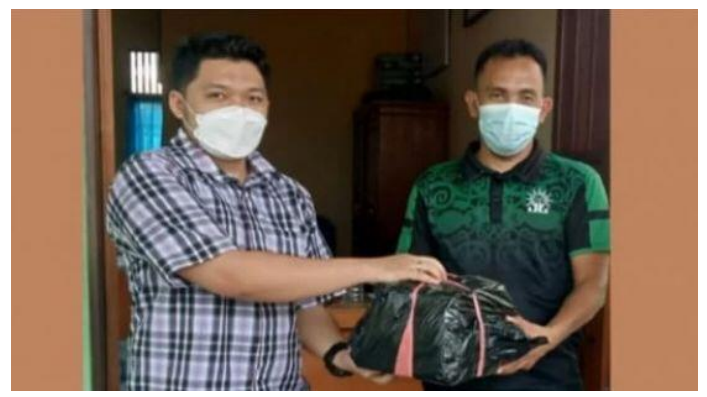

Gambar 5. Pemberian donasi buku ke sekolah 
Journal of Social Responsibility Projects by Higher Education Forum

Vol 2, No 2, November 2021, Page 98-103

ISSN 2723-1674 (Media Online)

Setelah mengadakan seminar via zoom, agenda selanjutnya yaitu memberikan donasi buku kepada SMA Muhammadiyah 2 Palangkaraya. Sebelum memberikan donasi buku, panitia melakukan koordinasi dengan Kepala Sekolah tentang kapan donasi buku dapat dilaksanakan. Hingga keputusan pun diambil. Kegiatan donasi buku dilaksanakan pada hari Selasa, 28 September 2021 Pukul 13.00 hingga Pukul 15.00 bertempat di Ruang Tata Usaha SMA Muhammadiyah 2 Palangkaraya.

\section{KESIMPULAN}

Pemberian penyuluhan seperti Trik Jitu Menguasai Matematika sangat diperlukan oleh siswa sebagai pemberian motivasi kepada siswa dalam belajar matematika serta tips-tips yang memudahkan siswa dalam belajar matematika sehingga prestasi belajar dalam bidang matematika semakin meningkat.

\section{DAFTAR PUSTAKA}

Barus, M.D.Br., \& Azzahra, A.S. (2020). Analisis Aplikasi dan Penerapan Matematika Pada Ilmu Ekonomi Fungsi Permintaan dan Penawaran. Jurnal Akuntansi Bisnis \& Publik, Vol. 11, No.1, Pp. 1-11

Kementrian Keuangan Republik Indonesia (2020). Program Pemulihan EkonomiNasional (PEN) [Press release]

Siagian, M.D. (2016). Kemampuan Koneksi Matematik Dalam Pembelajaran Matematika. Journal of Mathematics Education and Science, Vol. 2, No. 1, Pp. 58-67 